\title{
Airway inflammation, bronchial hyperresponsiveness and asthma in elite ice hockey players
}

\author{
A. Lumme, T. Haahtela, J. Öunap, P. Rytilä, Y. Obase, M. Helenius, V. Remes, I. Helenius
}

Airway inflammation, bronchial hyperresponsiveness and asthma in elite ice hockey players. A. Lumme, T. Haahtela, J. Ounap, P. Rytilä, Y. Obase, M. Helenius, V. Remes, I. Helenius. (C) ERS Journals Ltd 2003.

ABSTRACT: There is little information of lower respiratory symptoms, bronchial hyperresponsiveness and airway inflammation in elite ice hockey players.

A total of 88 highly trained ice hockey players and 47 control subjects were studied. All the subjects were subjected to skin-prick tests, resting spirometry examinations and histamine-challenge tests. Adequate induced sputum samples were obtained from 68 of the ice hockey players and from 18 symptom-free control subjects on a separate day.

Bronchial hyperresponsiveness in a histamine-challenge test was found in $21(24 \%)$ of the athletes and in five $(11 \%)$ of the controls. Current asthma (current asthmatic symptoms and increased bronchial responsiveness) was observed in $13(15 \%)$ of the athletes and in one $(2 \%)$ of the control subjects. Total asthma (current asthma or previously physician-diagnosed asthma) occurred in $19(22 \%)$ of the athletes and in two $(4 \%)$ of the controls. Atopy, according to skin-prick tests, was observed in $51(58 \%)$ of the athletes and $17(36 \%)$ of the control subjects. The differential cell counts of eosinophils (2.6 versus $0.2 \%)$ and neutrophils $(80.9$ versus $29.9 \%)$ in the sputum samples of the ice hockey players were significantly higher than in those of the control subjects.

Asthma is common in elite ice hockey players and they show signs of a mixed type of neutrophilic and eosinophilic airway inflammation. Inhalation of cold air associated with exposure to indoor pollutants during intensive training is a possible causative factor.

Eur Respir J 2003; 22: 113-117.
Dept of Allergy, Helsinki University Central Hospital, Helsinki, Finland.

Correspondence: I. Helenius, Arhipanpolku 8 b A, FIN-00420 Helsinki, Finland.

Fax: 358947186500

E-mail: ilkka.helenius@helsinki.fi

Keywords: Asthma

airway inflammation

ice hockey

sports medicine

Received: December 42002

Accepted after revision: February 52003

This study was funded by Helsinki University Central Hospital Grant 2302 and research grants from Merck, Sharp and Dohme International, the Ida Montin Foundation, the Väinö and Laina Kivi Foundation, and the Allergy Research Foundation.
Exercise may increase ventilation up to $200 \mathrm{~L} \cdot \mathrm{min}^{-1}$ for short periods of time in speed and power athletes, such as ice hockey players, and for longer periods in endurance athletes, such as cross-country skiers and swimmers [1].

Ice hockey players exercise or play intensively in cold air $\left(5-10^{\circ} \mathrm{C}\right)$ and cross-country skiers do so at even lower temperatures. LARSSON et al. [2] investigated the effect of a 2-h exposure to cold air on airway inflammation in healthy subjects. They found that cold air exposure induced increased numbers of granulocytes and macrophages in the lower airways. KARJALAINEN et al. [3] observed increased numbers of activated eosinophils, T-lymphocytes and macrophages in bronchial biopsy specimens from elite cross-country skiers. Airway inflammation has not previously been studied among ice hockey players.

PENNANEN et al. [4] recorded concentrations of carbon monoxide $(\mathrm{CO})$, nitric oxide (NO), and nitrogen dioxide $\left(\mathrm{NO}_{2}\right)$ in five Finnish ice hockey arenas that used combustion engines in ice resurfacers. The highest $1 \mathrm{~h}$ average $\mathrm{CO}$ and $\mathrm{NO}_{2}$ concentrations ranged $20-33 \mathrm{mg} \cdot \mathrm{m}^{-3}$ and $270-7,440 \mu \mathrm{g} \cdot \mathrm{m}^{-3}$, respectively. It was estimated that the highest indoor $\mathrm{NO}_{2}$ levels were $\sim 100$ times the levels measured in ambient outdoor air and 20 times the World Health Organization health-based air quality guidelines [4]. High concentrations of volatile organic compounds are significantly associated with fuel-powered ice resurfacing machines and the low volume and ventilation of the building [5]. Thus, ice hockey players are intensively exposed to cold air and often increased $\mathrm{CO}, \mathrm{NO}$ and $\mathrm{NO}_{2}$ concentrations.
Asthma occurrence seems to be higher among ice hockey players when compared with the normal population. LEUPPI et al. [6] studied 26 Swiss ice hockey players and 24 elite floor ball players. Increased bronchial responsiveness was found in $35 \%$ (nine of 26) of ice hockey players and in $21 \%$ (five of 24 ) of floor ball players. In Nagano, Japan, in 1998, WILBER et al. [7] observed exercise-induced bronchospasm in $15 \%$ of the USA female ice hockey team. In connection with a simulated long-skating programme, MANNIX et al. [8] found exerciseinduced bronchospasm in 35\% (43 of 124) of USA figure skaters.

The aim of the present study was to investigate the occurrence and characteristics of airway inflammation, atopy, increased bronchial responsiveness and asthma in a large group of elite ice hockey players.

\section{Materials and methods}

\section{Subjects and study design}

The study was carried out during November 2001February 2002. The ice hockey players were from three Finnish junior ice hockey teams playing at the highest national level (two teams from Helsinki and one from Espoo). All the players from these teams were given a brief description of the purpose of the study. From the 102 ice hockey players who attended the information session a total 
of $88(86 \%)$ took part in the study, $41 \%$ (36 of 88 ) of whom were from the Finnish junior national team. The 14 players who were unable to participate included three players who had reported physician-diagnosed asthma that they considered to be well controlled. Further participants asked to take part in the study included two courses of medical students $(n=126)$, who were randomly selected from the University of Helsinki. From these students, 79 were not willing to participate in this study and three of them reported physician-diagnosed asthma. Of the 126 medical students asked to take part in the study, $47(37 \%)$ students participated in the study. None of the medical students included in the study were involved in active competitive sports.

Physician-diagnosed asthma was reported by $9 \%$ (eight of 88 ) of the athletes, and by $2 \%$ (one of 47) of the control subjects (diagnosed early in childhood in the case of the control). Of these asthmatics, two ice hockey players and one control subject currently used inhaled corticosteroids. Additionally, three ice hockey players and one control subject used short-acting inhaled $\beta_{2}$-agonists when needed (table 1).

All examinations were performed on a day without training. Inhaled $\beta_{2}$-agonists were stopped for $12 \mathrm{~h}$ before the tests. The subjects answered a respiratory symptom questionnaire [10] and a more allergy-specific questionnaire [11], and were interviewed and clinically examined by one of the authors. The examinations included a skin-prick test [11], a resting spirometric examination $[9,12]$ and a histaminechallenge test [13]. Induced sputum samples were obtained from all ice hockey players and from a subgroup of 19 nonasthmatic, nonsmoking, symptom-free control subjects on a separate day (within 1 week of the pulmonary function tests, though not within the first $24 \mathrm{~h}$ ). From the 19 controls, seven were atopic according to skin-prick tests.

Skin-prick tests were made with 10 allergen extracts (Soluprick SQ, 10 histamine equivalent potency; ALK Abello, Horsholm, Denmark), and positive (histamine dihydrochloride, $10 \mathrm{mg} \cdot \mathrm{mL}^{-1}$ ) and negative (solvent) control solutions. The airborne allergens used were as follows: birch, timothy, meadow fescue and mugwort pollen; horse, cat, dog

Table 1.-Clinical characteristics

\begin{tabular}{lcc} 
Characteristic & $\begin{array}{c}\text { Ice hockey } \\
\text { players }\end{array}$ & Control subjects \\
\hline $\begin{array}{l}\text { Subjects n } \\
\text { M:F }\end{array}$ & 88 & 47 \\
$\begin{array}{l}\text { Age yrs } \\
\text { Duration of active } \\
\quad \text { sports career yr }\end{array}$ & $18.1 \pm 0.9$ & $36: 11$ \\
$\begin{array}{l}\text { Training in the } \\
\text { previous year h }\end{array}$ & $11.0 \pm 1.5$ & $26.7 \pm 6.0$ \\
$\begin{array}{l}\text { History of physician- } \\
\text { diagnosed asthma }\end{array}$ & $580 \pm 270$ & $170 \pm 130$ \\
$\begin{array}{l}\text { Exercise-induced } \\
\text { bronchial symptoms }\end{array}$ & $8(9)$ & $1(2)$ \\
$\begin{array}{l}\text { Current inhaled } \beta_{2} \text {-agonist } \\
\text { Current inhaled } \\
\quad \text { corticosteroid }\end{array}$ & $46(52)$ & $7(15)$ \\
$\begin{array}{l}\text { Family history } \\
\text { of asthma }\end{array}$ & $2(2)$ & $1(2)$ \\
$\begin{array}{l}\text { Current smoking } \\
\text { FEV } 1\end{array} \quad$ & $9(10)$ & $1(2)$ \\
$\quad \begin{array}{l}\text { \% } \\
\quad \text { p pred }\end{array}$ & $2(2)$ & $2(4)$ \\
\hline
\end{tabular}

Data are presented as mean \pm SD or $\mathrm{n}(\%)$ unless otherwise stated. M: male; F: female; FEV1: forced expiratory volume in one second; $\%$ pred: $\%$ predicted. ${ }^{\#}$ : reference values for adult Finns [9]. $* * *: p<0.001$. and cow dander; the mite Dermatophagoides pteronyssinus and mould spores of Cladosporium herbarum.

Resting spirometry was carried out according to the recommendations of the American Thoracic Society [12] with a flow/volume spirometer (heated pneumotachograph, Medikro 909; Medikro Oy, Kuopio, Finland). Values are expressed as percentages of reference (predicted) values for adult Finns [9].

Histamine challenges were performed by the dosimetric method with controlled tidal breathing using commercially available histamine diphosphate at $\mathrm{pH} 7.4$ [13]. Noncumulative histamine doses of $0.025,0.1,0.4$ and $1.6 \mathrm{mg}$ were inhaled and the forced expiratory volume in one second (FEV1) values measured $90 \mathrm{~s}$ after each inhalation. The dose of histamine that caused a $15 \%$ fall in FEV1 (PD15) was determined by logistic interpolation. Dose/response rates (DRR) were calculated as a fall in FEV1 divided by the maximal dose of histamine given [14].

Sputum was induced by inhalation of nebulised 5\% hypertonic saline using an ultrasonic nebuliser (OMRON U1ß; Omron, Tokyo, Japan) and no premedication was used [15]. Sputum was examined as described previously [15, 16]. Briefly, all sputum macroscopically free of salivary contamination was selected and treated with dithiothreitol

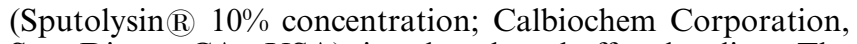
San Diego, CA, USA) in phosphate-buffered saline. The suspension was centrifuged. The cell pellet was resuspended and the absolute number of cells per milligram of processed sputum calculated. Coded cytospins were prepared and stained using May-Grünwald Giemsa stain in order to obtain a differential cell count. Differential cell counts of intact bronchial epithelial cells and leukocytes were made by counting a minimum of 400 nonsquamous cells. The cell counts, made by two investigators, blinded to the clinical characteristics of the study subjects, were averaged to yield the final percentages reported. The sputum sample was considered adequate if it contained $<80 \%$ squamous epithelial cell contamination from saliva.

All subjects gave their written informed consent and the study protocol was approved by the local ethics committee.

\section{Definitions}

A subject was classified as atopic if any allergen caused a weal of $\geqslant 3 \mathrm{~mm}$ in diameter, while control solutions gave expected results. Sensitisation to seasonal allergens was defined as at least one positive skin-test reaction to birch, timothy, meadow fescue, mugwort or Cladosporium herbarum. Sensitisation to perennial allergens was defined as at least one positive skin-test reaction to horse, cat, dog, cow dander or the mite Dermatophagoides pteronyssinus, without positive skin reactions to seasonal allergens. Increased bronchial responsiveness was defined as PD15 $\leqslant 1.6 \mathrm{mg}$ [13]. Current asthma was defined as increased bronchial responsiveness, together with at least one exercise-induced bronchial symptom occurring monthly during the last year (shortness of breath, wheeze or cough) [11]. Total asthma was defined as current asthma or asthma diagnosed previously by a physician [11]. Sputum eosinophilia was defined as a sputum differential eosinophil count of $>2 \%$ [17].

\section{Statistical methods}

Differences in the prevalence rates were examined by using Fisher's exact test. A Mann-Whitney U-test was used to 
Table 2.-Occurrence of atopy, increased bronchial responsiveness, current asthma and total asthma

\begin{tabular}{|c|c|c|c|}
\hline Characteristic & $\begin{array}{l}\text { Ice hockey } \\
\text { players }\end{array}$ & $\begin{array}{l}\text { Control } \\
\text { subjects }\end{array}$ & p-value $\#$ \\
\hline Subjects $n$ & 88 & 47 & \\
\hline Atopy & $51(58)$ & $17(36)$ & 0.025 \\
\hline $\begin{array}{l}\text { Increased bronchial } \\
\text { responsiveness }\end{array}$ & $21(24)$ & $5(11)$ & 0.097 \\
\hline Current asthma & $13(15)$ & $1(2)$ & 0.033 \\
\hline Total asthma & $19(22)$ & $2(4)$ & 0.011 \\
\hline
\end{tabular}

Data are presented as $\mathrm{n}(\%)$ unless otherwise stated. \#: Fisher's exact test.

examine the differences in continuous variables. Two-tailed p-values of $\leqslant 0.05$ were considered significant.

\section{Results}

\section{Clinical and pulmonary function data}

A total of $52 \%$ (46 of 88 ) of the ice hockey players and $15 \%$ (7 of 47) of the control subjects reported exercise-induced bronchial symptoms monthly during the last year $(\mathrm{p}<0.001)$ (table 2). Three athletes had abnormally low FEV1/forced vital capacity ratio (absolute values $<70 \%$ ) and one abnormally low FEV1 ( $<80 \%$ of predicted) in the resting flow/ volume spirometry [9]. FEV1 values (\% pred) were significantly higher in the athletes compared with control subjects $(\mathrm{p}=0.00019$; table 1). Increased bronchial responsiveness was observed in $24 \%$ (21 of 88 ) of the athletes and $11 \%$ (five of 47 ) of controls $(\mathrm{p}=0.097)$. The mean (range) DRR values $\left(\% \cdot \mathrm{mg}^{-1}\right)$ were $9.26(0.29-160.3)$ in the ice hockey players and 4.26 $(0-11.88)$ in the control subjects $(\mathrm{p}=0.012)$. Current asthma was observed in 15\% (13 of 88) of the athletes and in $2 \%$ (one of 47$)$ of the control subjects $(\mathrm{p}=0.033)$. Total asthma occurred in $22 \%$ (19 of 88 ) of the athletes compared with $4 \%$ (two of 47 ) of the control subjects $(\mathrm{p}=0.011)$.

Atopy was found in $58 \%$ (51 of 88 ) of the athletes and in $36 \%$ (17 of 47$)$ of the control subjects $(p=0.025)$. Seasonal sensitisation was shown in $47(53 \%)$ of the athletes and 15 $(32 \%)$ of the control subjects. Perennial sensitisation was observed in four $(5 \%)$ athletes and two $(4 \%)$ control subjects in skin-prick tests. Atopic athletes tended to have a higher frequency of total asthma when compared with nonatopic athletes $(\mathrm{p}=0.062)$.

\section{Sputum data}

A total of $20(23 \%)$ ice hockey players and one $(5 \%)$ control subject failed to give adequate sputum samples (table 3 ). One of the 68 ice hockey players who gave induced sputum samples was a current smoker. None of the subjects experienced any adverse effects during induction. None of the subjects had a history of upper or lower respiratory tract infection 4 weeks before sputum induction.

No significant differences in total nonsquamous sputum cell counts existed between the ice hockey players and control subjects (table 3 ). The differential cell counts of lymphocytes and bronchial epithelial cells were also similar in both groups. Sputum from the athletes had significantly higher differential cell counts of eosinophils and neutrophils than sputum from the control subjects ( $\mathrm{p}=0.039$ and $\mathrm{p}<0.001$, respectively). Sputum eosinophilia (eosinophil count $>2 \%$ ) was found in $15 \%$ (10 of 68$)$ of the athletes and in none of the control subjects $(\mathrm{p}=0.084)$.

No significant difference was observed in the sputum differential eosinophil or neutrophil counts between symptomatic and symptom-free ice hockey players. Atopic and nonatopic athletes had similar quantities of sputum eosinophils and neutrophils. No significant difference was observed in the sputum eosinophil or neutrophil cell counts between athletes with and without bronchial hyperresponsiveness (BHR). No correlation was observed between PD15 values and sputum differential eosinophil counts in the 21 players with BHR.

\section{Discussion}

The present study shows that asthma and atopy are significantly more common in elite ice hockey players compared with control subjects. In addition, ice hockey players have signs of a mixed type of neutrophilic and eosinophilic airway inflammation that differed significantly from control subjects. However, no correlation was observed between the severity of eosinophilic or neutrophilic airway inflammation and BHR or bronchial symptoms.

\section{Validity of the data}

The subjects of the present study were recruited from three Finnish junior ice hockey teams and the control subjects from the University of Helsinki. Self-selection may have happened, with healthier or symptom-free subjects less likely to take part. However, such selection should have happened in control subjects to an equal extent. The occurrence of asthma in those subjects not participating in the present study was recorded. Fourteen athletes and 79 potential control subjects were not able to participate in this study. In both groups, three subjects reported a previous history of asthma. The study groups were not exactly similar with respect to age and sex. The control subjects were older, which could have a cumulative effect on the occurrence of symptoms and therefore total asthma. Current asthma was defined as

Table 3.-Comparison of sputum diffential cell counts between ice hockey players and control subjects

\begin{tabular}{lccc}
\hline & Ice hockey players & Control subjects & p-value \\
\hline Subjects n & 68 & 18 & \\
Total cell count $10^{3} \cdot \mathrm{mg}^{-1}$ & $5.1(0.6-24.5)$ & $4.6(0.1-14.6)$ & $\mathrm{NS}$ \\
Eosinophils & $2.6(0-64.7)$ & $0.2(0-1.3)$ & 0.039 \\
Neutrophils & $00.9(17.9-98.8)$ & $29.9(0.5-86.2)$ & $<0.001$ \\
Lymphocytes & $0.5(0-3.7)$ & $0.6(0-1.5)$ & 0.35 \\
Macrophages & $15.8(0.9-85.5)$ & $66.2(13.2-99.5)$ & $0.2(0-2.6)$ \\
Bronchial epithelial cells & $0.3(0-5.9)$ & 0.001 \\
\hline
\end{tabular}

Data are presented as mean (range) unless otherwise stated. NS: nonsignificant. " ${ }^{\text {: }}$ Mann-Whitney U-test. 
bronchial responsiveness and at least one exercise-induced bronchial symptom occurring monthly during the previous year. Symptoms induced by exercise were selected for the definition, because they commonly appear as one of the first symptoms or signs of asthma [18]. Additionally, all participants were young, active adults who, including controls, performed physical exercise and would therefore have easily noticed problems in breathing.

\section{Comparison with previous data}

LEUPPI et al. [6] studied 26 elite ice hockey players and 24 elite floor ball players by use of methacholine-challenge tests, exercise-challenge tests and respiratory symptom questionnaires. BHR in a methacholine test was found in nine $(35 \%)$ and asthma (BHR and symptoms) in five $(19 \%)$ of the ice hockey players. WILBER et al. [7] studied 26 female USA Olympic team ice hockey players using an actual competition with lung function measurements. From their studies, four players showed exercise-induced bronchospasm (FEV1 decreased $10 \%$ compared with baseline). These figures correspond well with those in the present study, with 21 (24\%) showing BHR, $13(15 \%)$ current and $19(22 \%)$ total asthma.

Recently, HoLzer et al. [19] studied 50 elite summer sports' athletes using methacholine and eucapnic hyperventilation tests. Nine showed BHR in the methacholine test and 25 in the eucapnic hyperventilation test. The authors concluded that airway responsiveness to dry air can occur in the absence of BHR to a pharmacological challenge. Thus, the present study may somewhat underestimate the occurrence of BHR and asthma, since in the current study airway responsiveness was measured using only a single mediator (histamine).

Ice hockey players exercise or play intensively in cold air $\left(5-10^{\circ} \mathrm{C}\right)$, and cross-country skiers do so at lower temperatures. LARSSON et al. [2] investigated the effect of a 2-h exposure to cold air on airway inflammation in healthy subjects. They found that cold air exposure induced increased numbers of granulocytes and macrophages in the lower airways. KARJALAINEN et al. [3] observed increased shares of T-lymphocytes, neutrophils and eosinophils in the lamina propria of bronchial biopsy samples from highly trained cross-country skiers. Previously, these authors observed that mild eosinophilic and lymphocytic airway inflammation were aggravated in swimmers who remained active during a 5-yr prospective follow-up study [20]. In contrast, in swimmers who stopped active training, eosinophilic airway inflammation, BHR and asthma became attenuated or even disappeared. The swimmers had also shown signs of a mixed type of neutrophilic and eosinophilic airway inflammation in induced sputum samples [16]. In the present study, ice hockey players showed signs of a mixed type of neutrophilic and eosinophilic airway inflammation.

Much increased ventilation during exercise, combined with exposure to cold air, $\mathrm{NO}$ and $\mathrm{CO}$ may be responsible for asthma-like symptoms and airway inflammation in the present study's athlete group [4, 5]. The irritant-induced airway inflammation observed in elite athletes may differ significantly from the inflammation observed in nonathlete asthmatics. Athletes' asthma seems to show airway inflammation with predominance of neutrophils over other cell types. This inflammation may respond poorly to conventional treatments [21] (I. Helenius, Helsinki University Central Hospital, unpublished results), but appears to be partly reversible after stopping intensive training [20]. The sputum differential cell count of the athletes is also very similar to that observed in patients with lower respiratory tract infection [22].

To conclude, bronchial hyperresponsiveness and asthma were more common in highly trained Finnish ice hockey players than in other young adults. Eosinophilic airway inflammation affected one-tenth of the ice hockey players. The mechanism for increased occurrence of asthma in this population is unclear, but increased exposure to cold air and indoor pollutants are possible causative factors.

\footnotetext{
Acknowledgements. The authors would like to thank S. Sarna for help with the statistical analyses. M. Tokoi and H. Punkari are also acknowledged for their technical help.
}

\section{References}

1. Helenius I, Haahtela T. Allergy and asthma in elite summer sports athletes. J Allergy Clin Immunol 2000; 106: 444- 452.

2. Larsson K, Tornling G, Gavhed D, Muller-Suur C, Palmberg L. Inhalation of cold air increases the number of inflammatory cells in the lungs in healthy subjects. Eur Respir J 1998; 12: 825-830.

3. Karjalainen EM, Laitinen A, Sue-Chu M, Altraja A, Bjermer L. Evidence of airway inflammation and remodeling in ski athletes with and without bronchial hyperresponsiveness to methacholine. Am J Respir Crit Care Med 2000; 161: 20862091.

4. Pennanen AS, Salonen RO, Alm S, Jantunen MJ, Pasanen P. Characterization of air quality problems in five Finnish indoor arenas. J Air Waste Management Assoc 1997; 47: 1079-1086.

5. Hedberg K, Hedberg CW, Iber C, et al. An outbreak of nitrogen dioxide-induced respiratory illness among ice hockey players. JAMA 1989; 262: 3014-3017.

6. Leuppi JD, Kuhn M, Comminot C, Reinhart WH. High prevalence of bronchial hyperresponsiveness and asthma in ice hockey players. Eur Respir $J$ 1998; 12: 13-16.

7. Wilber RL, Rundell KW, Szmedra L, Jenkinson DM, Im J. Incidence of exercise-induced bronchospasm in Olympic winter sport athletes. Med Sci Sports Exerc 2000; 32: 732737.

8. Mannix ET, Farber MO, Palange P, Galassetti P, Manfredi F. Exercise-induced asthma in figure skaters. Chest 1996; 109: 312-315.

9. Viljanen A. Reference values for spirometric, pulmonary diffusing capacity, and body plethysmographic studies. Scand J Clin Lab Invest 1982; 42: Suppl. 159, 1-50.

10. Helenius IJ, Tikkanen HO, Haahtela T. Association between type of training and risk of asthma in elite athletes. Thorax 1997; 52: 157-160.

11. Helenius IJ, Tikkanen HO, Sarna S, Haahtela T. Asthma and increased bronchial responsiveness in elite athletes: atopy and sport event as risk factors. J Allergy Clin Immunol 1998; 101: 646-652.

12. American Thoracic Society. Standardization of spirometry 1987 update. Am Rev Respir Dis 1987; 121: 1285-1298.

13. Sovijärvi ARA, Malmberg $\mathrm{P}$, Reinikainen K, Rytilä P, Poppius H. A rapid dosimetric method with controlled tidal breathing for histamine challenge. Repeatability and distribution of bronchial reactivity in a clinical material. Chest 1993; 104: 164-170.

14. O'Connor G, Sparrow D, Taylor D, Segal M, Weiss S. Analysis of dose-response curves to methacholine. An approach suitable for population studies. Am Rev Respir Dis 1987; 136: 1412-1417.

15. Metso T, Kilpiö K, Björksten F, Kiviranta K, Haahtela T. Can early asthma be confirmed with laboratory tests? Allergy 1996; 51: 226-231. 
16. Helenius IJ, Rytilä $\mathrm{P}$, Metso $\mathrm{T}$, Haahtela $\mathrm{T}$, Venge $\mathrm{P}$, Tikkanen HO. Respiratory symptoms, bronchial responsiveness and cellular characteristics of induced sputum in elite swimmers. Allergy 1998; 53: 346-352.

17. Belda J, Leigh R, Parameswaran K, O'Byrne PM, Sears MR, Hargreave FE. Induced sputum cell counts in healthy adults. Am J Respir Crit Care Med 2000; 161: 475-478.

18. Anderson SD, Daviskas E. Pathophysiology of exerciseinduced asthma: the role of respiratory water loss. In: Weiler JM, ed. Allergic and Respiratory Disease in Sports Medicine. New York, Marcel Dekker Inc., 1997; pp. 87-114.

19. Holzer K, Anderson SD, Douglas J. Exercise in elite summer athletes: Challenges for diagnosis. J Allergy Clin Immunol 2002; 110: 374-380.
20. Helenius I, Rytilä P, Sarna S, et al. Effect of continuing or finishing high-level sports on airway inflammation, bronchial hyperresponsiveness and asthma. A prospective follow-up study of 42 elite swimmers. J Allergy Clin Immunol 2002; 109: 962-968.

21. Sue-Chu M, Karjalainen EM, Laitinen A, Larsson L, Laitinen LA, Bjermer L. Placebo-controlled study of inhaled budesonide on indices of airway inflammation in bronchoalveolar lavage fluid and bronchial biopsies in cross-country skiers. Respiration 2000; 67: 417-425.

22. Metso T, Rytilä P, Peterson C, Haahtela T. Granulocyte markers in induced sputum in patients with respiratory diseases obtained by two sputum processing methods. Respir Med 2001; 95: 48-55. 